Kovalenko A.M. (2006). Tvyerdyye bytovyye otkhody. Problemy i resheniya. Tekhnologii, oborudovaniye. [Municipal solid waste. Problems and solutions. Technologies, equipment]. Kharkov: KhNAGKh, 301 p. (Rus.)

79. Nanda S.,. Berruti F. (2021). Municipal solid waste management and landfilling technologies: a review. Environmental Chemistry Letters, 19, pp. 1433-1456. - https://doi.org/10.1007/s10311-02001100-y

80. Klemeš J.J., Fan Y.V., Jiang P. (2021). Plastics: friends or foes? The circularity and plastic waste footprint. Energy Sources, Part A: Recovery, Utilization, and Environmental Effects, 43 (13), pp. 1549-1565. - https://doi.org/10.1080/15567036. 2020.1801906

81. Vollmer I., Jenks M.J.F., Roelands M.C.P.,
White R.J., Harmelen van T., de Wild P., Laan van der G.P., Meirer F., Keurentjes J.T.F., Weckhuysen B.M. (2020). Beyond Mechanical Recycling: Giving New Life to Plastic Waste. Angewandte Chemie International Edition, 59, pp. 15402-15423. doi: 10.1002 / anie.201915651

82. Abukasim S.M., Zuhria F., Saing Z. 2019. Alternative management of plastic waste. Journal of Physics: Conference Series. 1st Borobudur International Symposium on Applied Science and Engineering (BIS$A S E), 1517$, Article 012041, 7 p. doi: 10.1088/1742$6596 / 1517 / 1 / 012041$

83. Mikulionok I.O. (2001). Osnovni metody vukorystannia gumovmisnykh vidkhodiv. [Basic methods of using rubber-containing waste]. Khimichna promyslovist Ukrainy. No. 5, pp. 53-58. (Ukr.)

Received April 21, 2021

Seryogin O.O. ${ }^{1}$, Doctor of Technical Sciences, Vasylenko O.V.', Candidate of Technical Sciences, Frank J. Riedel ${ }^{2}$, Helmut Aigner ${ }^{2}$

${ }^{1}$ National University of Food Technologies, Kyiv 68, Volodymyrska,01033 Kiev, Ukraine, e-mail: seryoginoo@ukr.net

${ }^{2}$ Ingenieurplanungsgruppe $\mathrm{GmbH}$, München

27, Christoph-Rapparini-Bogen, 80639 München, Germany, e-mail: Intereng.riedel@t-online.de

\title{
Technological Complex for Processing of Solid Household and Treatment Facilities Waste with Biogas Obtaining
}

\begin{abstract}
A concept has been developed for processing of biologically active sludge from municipal wastewater treatment plants in combination with the organic fraction of municipal solid waste using the BioTech Process. The complex, which makes it possible to implement the proposed concept, does not require additional land plots, and classified secondary raw materials, biogas and high-quality biofertilizers suitable for use in the agricultural industry are the products of its activity. The proposed concept will allow solving several problems at once due to the construction of a waste recycling plant on the territory of the filtration zone of the existing water treatment facilities. The new processing plant will be used not only for processing and sorting of solid waste, but also for treating sludge from wastewater treatment plants, together with organic waste obtained from solid waste in the BioTech Process to obtain biogas and biofertilizers, the so-called compost. The new recycling plant will be environmentally friendly and, among other benefits, will be able to process of municipal solid waste with preliminary sorting and separation of recyclable materials. Bibl. 9, Fig. 1.
\end{abstract}

Key words: biogas, municipal solid waste, sewage treatment, recycling, compost. 
In Ukraine, operates more than 5,000 sewage treatment plants that are not profitable and create a significant burden on local budgets. In addition, almost all of them work on obsolete technological schemes without the use of biogas technology, which would allow partially offset the cost of natural gas - biogas.

Recently, the situation escalated to the operation of municipal solid waste (MSW) in Ukraine, major problem - this environmental condition of the air, groundwater and pollution. And the main reason that unites these two problems is the processing of organic waste by methanation.

Proposal provides for no new construction and renovation of existing treatment facilities for the destruction of fields and mud on their completion of the city stations, sorting and recycling of unsorted municipal solid waste processing technologies in the organic component of a complex with components of the silt waste water by methanation.

Placement of the proposed technology in treatment facilities will achieve maximum effectiveness as a treatment of municipal solid waste and wastewater with the use of alternative energy technologies, with minor costs for the reconstruction of treatment facilities.

Using the modern world of wastewater treatment technology [Dunser. Aigner. Kollegen Ingenieurplanungsgruppe GmbH (Helmut Aigner)] help to produce water that will meet the standards for technical use of water and irrigation.

\section{State of Problem}

In Ukraine and around the world, society is increasingly beginning to recognize the problem of waste disposal. Existing landfills reaching maximum capacity, the new harder to find, even harder to get a license, and almost impossible to reconcile all the local authorities the power structures.

These problems are quite obvious and relevant than in large cities "millionaire" and for smaller towns.

Strengthening environmental legislation requires costly training and special precautions in unexpected reactions of unprotected waste water and emissions of biogas [1].

These facts, as well as monitoring and research for 20 years after the operation of the landfill indicate that this type of recycling is relatively expensive and inefficient way of disposal of solid waste.
Crucial for a bio-methanation process, which eliminates the use of the above sources of the problem. In fact, it is a natural process that occurs after the trash was buried and the process was uncontrolled and the release into the environment of the product schedule, but in this case, the waste is transported in containers indoors. Controlled temperature and other conditions accelerate the process of biological fermentation, which usually occurs within a year to less than 15 days, which significantly reduces the need for landfill space of a few hectares, and also contributes to the avoidance of any kind or kinds of radiation.

Processing plants and garbage disposal by methanation can be installed even at 200 meters from residential areas - they are very safe and ecological.

This method of waste disposal, which was developed in Germany, to reduce the waste volume to about $10-25 \%$ of its original volume and is able not only to cover the costs of its implementation and operation, but will make a profit. Producing biogas (methane) and manure of high biological quality, which can be sold on a commercial basis, thus reducing costs for waste disposal to a level comparable to modern "sanitary" landfills including those which have to carry away waste.

In communities throughout the world, the public is becoming increasingly aware of the waste disposal problem. While existing landfills are reaching capacity, new ones are becoming hard to find, harder to license, and next to impossible to get accepted by the local residents.

These problems are extremely evident and urgent for touristic places.

Increasing environmental protection laws require expensive preparation and precautions against unguarded leachate and biogas emissions. This together with up to 20 years of supervision even after completing the landfill site make this type of waste management also a rather expensive undertaking.

This document discusses the BioTech Process, which avoids the above cited problems at the source. Actually the natural process, which takes place in a landfill site, is transferred into closed buildings and tanks. Controlled temperature and other process conditions accelerate the biological fermentation from years to less than 15 days, thus considerably reducing the required area of several hectares in a landfill site, and any kind of emission of whatsoever kind can be avoided. BioTech plants 
can be safely installed only $200 \mathrm{~m}$ away from inhabited areas [2].

This process, developed in Germany, reduces volume of waste to approximately $10-25 \%$ of its original figure and is capable to more than cover its operational costs by producing Bio-Gas (methane gas) and high quality biological compost, which can be sold commercially, thus reducing the waste management costs to levels comparable to modern "sanitary" landfills including transport to far away sites.

The specific advantages of the BioTech Process are:

- The fermentation process takes place in closed tanks, so that no environmental affects like smell or ground water contamination will occur, i.e. it can be installed in populated neighbourhoods. Reference plants in Germany can prove this fact!

- It requires only approx. 2 weeks for complete fermentation of bio-organic garbage into fertile compost, so that the required space is quite limited. A BioTech plant requires only a limited area.

- A BioTech plant produces biogas/electricity and a high quality compost, both highly valuable cash products. The compost will replace large quantities of artificial fertilizer thus supporting the trend for "ecological" agriculture. By selling these products it will fully cover its operational costs.

- Unusable and toxic matter (like batteries, for example) are automatically separated from the garbage in the initial stage of processing, so that there is no danger of contaminating the final compost.

- The residual fractions of the waste (like plastics, glass, metals) are eliminated clean and free from organic particles, so they may be safely sorted, recycled or even put on landfills again [3, 4].

\section{The BioTech Garbage Disposal Concept}

The specific advantage of the proposed BioTech Technology is a very accurate separation of the organic fraction of the waste from inert and toxic materials like plastics, batteries, glass, etc.

Normal waste processing plants with manual or semi-automatic sieving/sorting can never achieve $100 \%$ separation of the organic components.

The BioTech Process solves this problem in a very elegant way: The entire batch is dissolved in water and disintegrated by heavy agitation. The dissolver is designed in such a way as to reduce particle size of the organics to less than $10 \mathrm{~mm}$, while the plastic material remains practically unaffected. This makes the slip ready for separation by sieving, while heavy particles will be separated by gravity.

This guarantees a resulting compost of extremely high quality and purity $[2,5,6]$.

\section{Products obtained from BioTech Process}

The main products gained from the BioTech Process are:

1. Bio-Gas is an inflammable gas, which contains about $65-75 \%$ of pure methane, which is the main constituent of natural gas. The calorific value of Bio-Gas reaches approximately $6.5 \mathrm{kWh} / \mathrm{m}^{3}$, equivalent to $5600 \mathrm{kcal} / \mathrm{m}^{3}$.

This gas will be used for electricity generation in a decentralised power plant. However it is also ideally suitable for direct consumption in an industrial plant (ceramic or brick plant, chemical industry etc.) or it may be fed into the municipal city gas network for cooking and heating purposes.

2. Compost gained form BioTech Process (by anaerobic fermentation) is an extremely valuable soil improving material for all types of agriculture compost gained from anaerobic fermentation is much more easily accessible to the plants. It is usually completely digested within one season, while compost from traditional aerobic composting plants requires up to 4 years for complete absorption. This makes dosing of the appropriate quantities much easier and more accurate:

- Compost has a high contents of huminous acid, which reactivates "dead" soil, that has been overexploited by extensive use of chemical fertilizer. It breaks up the inert crust surrounding the soil granules, thus giving access of the plant roots to idle laying nutrients.

- Compost improves the binding forces between soil granules thus preventing wind erosion.

- Compost has a stable grain structure which assures a loose top soil with optimum soil aeration and water maintenance conditions.

- Compost neutralises soil acidity and stabilises the $\mathrm{pH}$-value of the soil.

- Compost despite of its origin has a very agreeable smell, similar to fresh forest earth.

- Due to the separation of contagious matter (like batteries for example) right from the beginning of the process, the contents of toxic matter like lead, mercury or other heavy metals and other soil contaminating substances is far below the per- 
missible standards. It will easily meet EC standards as well as U.S. EPA regulations.

- Extensive tests in German plant research institutions have proven a $9 \%$ higher plant growth yield against ordinary compost and even a $15 \%$ higher yield against ordinary peat commonly used at present for similar purposes.

- As an average compost may be used in agriculture in quantities up to $10 \mathrm{t}$ per hectare and season. It substitutes chemical fertilizers worth up to 150 EUR per hectare and season (60 EUR/acre).

- Compost is a highly valuable cash product, which may be even exported in substitution of natural peat, and which can be sold in bulk for about 15-25 EUR $/ \mathrm{m}^{3}$, depending on market circumstances. If the plant is equipped with an additional bag filling plant, it may be sold in bags of 20 and 50 liters to private gardeners for about 4 times this price [7].

3. The inert materials within the waste such as paper, plastics, glass, metals and pure sand (as construction material) are separated from the process clean and also sorted according to their specifications, so that they can be reused as recycling material. These recycling products have a ready international market which make marketing and sale relatively easy. The additional revenues recovered from such recycled materials will considerably increase the overall profitability [8].

\section{Description of BioTech Process}

Municipal Household Waste is a very problematic substance due to its heterogeneity and inconsistency. It consists of an undefined mixture of organic material with varying degrees of inert materials. Thus a plant for treating of household waste requires a high degree of flexibility.

The basic advantage of the BioTech Process is, that it can treat such a great variety of household or industrial refuse. The separation of the organic fraction from the inert (contaminating) material is achieved by dissolving the garbage and subsequent separation by gravity and sieving in a very elegant and efficient way.

The BioTech Process may treat without modifications such a wide variety of refuse: tions;

- organic household waste in various composi-

- industrial waste (organic and paper, from food and canning industries for example);
- agricultural wastes such as remains from olive pressing, from canning of citrus fruit, from grapes after pressing, etc.;

- agricultural animal waste and manure;

- waste from the gastronomic industry;

- slaughter houses waste;

- sludge from settling tanks and wastewater treatment plants;

- garden trimmings.

There are no requirements as to the purity or pre-classification of the input refuse material.

Up to $50 \%$ of foreign, non-organic material may be digested by the plant without problems.

In order to reduce initial investment costs, a manual pre-sorting of the waste has been envisaged. Few unskilled persons are required on a continuous conveyor belt to eliminate those particles like metal, plastics, paper etc. which may be suitable for recycling. They may be recruited from the scavengers which actually search the waste landfill sites, thus further guaranteeing them their income [6].

This manual presorting can never be $100 \%$ effective. Still about 10-15\% of inert material will remain undetected in the waste, which will be eliminated by the process technology.

Remaining heavy particles like batteries, stones, glass will be automatically eliminated from the process after dissolving the waste in water by gravity separation, and small quantities of remaining plastics will be sieved off so that the obtained compost maintains highest standards for agricultural applications.

Below is Technological diagram of the BioTech Process for the processing of municipal solid waste (Fig. 1).

\section{Preparation}

Garbage is delivered by truck into the preparation building. This building is equipped with exhaust fans and bio-filters, which assure that no smells escape into the environment.

The waste is directly emptied into a storage area. This stock can bridge a one-day-delivery of waste.

The waste is taken up with a pay loader which is equipped with a crusher shovel. While emptying the waste out of the shovel it passes the grinding equipment set at $150 \mathrm{~mm}$. This will just open plastic bags and other packaging material so that the waste becomes accessible for further treatment. The loosened waste stream passes a coarse screening machine (1) $(>80 \mathrm{~mm})$. The oversize practi- 


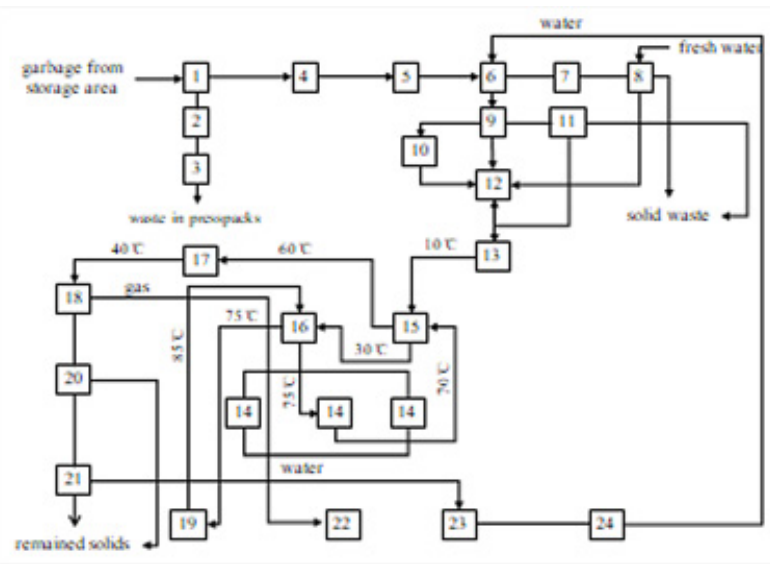

Fig. 1. Technological diagram of the BioTech Process for the processing of municipal solid waste: 1 - Coarse screen machine; 2 - Sorting conveyer; 3 - Baling press; 4 Magnetic metal separator; 5 - Pre-crusher; 6 - Turbodissolver tank; 7 - Steep screw conveyor; 8 - Vibrating screen; 9 - Vibrating dewatering screen; 10 - Pressworm separator; 11 - Sand separation tank; 12 - Underground reservoir; 13 - Buffer tank; 14 - Separate tanks; 15, $16-$ Exchangers; 17 - Air coolers; 18 - Digester/fermentation tank; 19 - Motor-generator set; 20, 21 - Screen press; $22-$ Gas storage tank; 23 - Separate tank; 24 - Pump.

cally contains no organic material and will pass a sorting conveyors (2), where a certainamount of recyclables such as paper, metals, different plastic, glass, may be sorted out, while the remaining bulk of inert material shall be sent to incineration or even landfilling. The eliminated materials are baled in a baling press (3) in order to reduce transport volume.

The undersize material from the screen ( $<80 \mathrm{~mm}$ ) will contain the bulk of the organic material but still approx. 20-30 \% non organics. This material passes a magnetic metal separators (4) before it is crushed (5) once again to about $40 \mathrm{~mm}$ and then transported to the turbo-dissolver tank (6).

Water is added and by imposing high shearing forces, the organic material is disintegrated down to fibre size to form a pasty slip, while the inert materials are practically not affected.

Heavy components like broken glass, batteries, stones, metal parts etc. are sinking to the bottom and are discharged from the slurry via steep screw conveyor (7). They are dewatered on a vibrating screen (8) and spray-washed.

The slurry is gradually emptied onto a vibrating dewatering screen (9). The non-disintegrated inert materials are then compacted and dewatered in a pressworm separator (10). The screened slurry passes a sand separation tank (11).

Depending on the further disposal possibilities for inert materials, the inert material may be washed in a separate washing tank, then dewatered and compacted again.

The remaining slurry, now practically pure organic material, is collected in an underground reservoir (12) and then pumped to the buffer tank (13) holding a storage capacity of $2-3$ days in order to assure a certain homogenisation of various input materials [2, 9].

\section{Pasteurisation, Fermentation}

Depending on local legislation the ready slurry/suspension shall be pasteurised (retention for one hour at $70{ }^{\circ} \mathrm{C}$ ) in separate tanks (14) in order to immobilise pathogens and active seeds. By heat exchangers $(15,16)$ the slurry is brought to the required temperature of $70{ }^{\circ} \mathrm{C}$, using the cooling water of the motor generator-sets (19). Through air coolers (17) the temperature of the slurry is then reduced to the $37^{\circ} \mathrm{C}$ required by the digesters.

The slurry is pumped into the Bio-Reactor or digester / fermentation tank (18) for anaerobic fermentation (fermentation under elimination of air access).

Micro-bacteria start the fermentation process and disintegrate the organic material thus forming the Bio-Gas.

The slurry in the digester will be constantly mixed by reintroducing part of the generated biogas.

In a continous process fresh slurry is fed into the Bio-Reactor and simultaneously fermented liquid is drained from it.

The fermentation process requires approx. 1520 days to form a stable non-odorous compost material $[3,4]$.

\section{Treatment of Final Products}

The liquid fraction of the digested slurry is dewatered in a dewatering screen press (20) in order to separate the remaining solids. This solid fraction, called Bio-Compost, forms a stable soil substrate, a compost-like material with an agreeable smell, which may be directly used for soil improvement in agricultural applications.

Excess water is screened again (21) in order top remaining solid particles.

The compost may be stored on an open surface 
for final maturing for another 2-4 weeks.

The generated gas is transported into a gas storage tank (22) via filters suitable for drying and purification (elimination of Hydrogen Sulfide $\mathrm{H}_{2} \mathrm{~S}$ ) from where it is conveyed to the motor-generator set (19). Biogas in case of maintenance of the generator or absence of any direct consumer is flared off in a special flare.

The remaining liquid from the pressworm treatment is partly reused for dissolving of fresh waste in the preparation hall, and excess water is stored in a separate tank (23). It forms a highly nutritious fertilizer, which can be directly sprayed onto the fields or added to irrigation water. However also discharge directly into the public sewagesystem or into a simple biological treatment plant is safe. Water from separate tank is also pumped by pump (24) to turbo-dissolver tank (6) [3, 4].

\section{References}

1. Biogas plants in Europe: a practical handbook, Myriam Demuynck, M. Demuynck, Edmond-Jacques Nyns, Wolfgang Palz, Commission of the European Communities, D. Reidel for the Commission of the European Communities, 1984. 339 pages.
2. A combined two-stage Process to "Zero-Residue" Solution Processing and Disposal of unsorted, unsegregated Muncipal Solid Waste. Frank Riedel. Presentation at ATHENS2014 International Conference on Sustainable Solid Waste Management.

3. The microbiology of anaerobic digesters, Michael H. Gerardi, John Wiley \& Sons, 18 Aug. 2003. 177 pages.

4. Biomethanization of the organic fraction of municipal solid wastes, J. Mata-Alvarez, IWA Publishing, 2003. 323 pages.

5. Biogas and waste recycling: the Philippine experience, Felix D. Maramba, Enrico D. Obias, Maya Farms Division, Liberty Flour Mills, 1978. 230 pages.

6. Biogas from waste and renewable resources: an introduction, Dieter Deublein, Angelika Steinhauser, Wiley-VCH, 18 Apr. 2008. 443 pages.

7. Compost, fertilizer, and biogas production from human and farm wastes in the People's Republic of China, Michael McGarry, Jill Stainforth, International Development Research Centre, 1978. 94 pages.

8. Resource recovery and reuse in organic solid waste management, Piet Lens, IWA Publishing, 2004. 516 pages.

9. Biogas plants: design and detail of simple biogas plants, Ludwig Sasse, German Appropriate Technology Exchange, Vieweg, 1984. 85 pages.

Received March 27, 2021

Серёгин А.А. ${ }^{1}$, докт. техн. наук, Василенко А.В. ${ }^{1}$, канд. техн. наук, Frank J. Riedel ${ }^{2}$, Helmut Aigner ${ }^{2}$

${ }^{1}$ Национальный университет пищевых технологий, Киев ул. Владимирская, 68, 01033 Киев, Украина, e-таil: seryoginoo@ukr.net

${ }^{2}$ Ingenieurplanungsgruppe GmbH, München

27, Christoph-Rapparini-Bogen, 80639 München, Germany, e-mail: Intereng.riedel@t-online.de

\section{Технологический комплекс по переработке твердых бытовых отходов и отходов очистных сооружений с получением биогаза}

Разработана концепция переработки биологически активного ила коммунальных очистных сооружений в комплексе с органической фракцией твердых бытовых отходов способом BioTech. Комплекс, позволяющий реализовать предложенную концепцию, не требует дополнительных земельных участков, а классифицированное вторичное сырье, биогаз и высококачественное биоудобрение, пригодное для использования в сельскохозяйственной 
промышленности, являются продуктами его деятельности. Предлагаемая концепция позволит решить сразу несколько задач за счет строительства мусороперерабатывающего завода на территории фильтровальной зоны существующих водоочистных сооружений. Новый перерабатывающий завод будет использоваться не только для обработки и сортировки муниципальных твердых бытовых отходов, но и для обработки ила от водоочистных сооружений совместно с органическими отходами в процессе BioTech для получения биогаза и биоудобрений - так называемого компоста. Новый перерабатывающий завод будет экологически чистым предприятием и, помимо прочих преимуществ, сможет перерабатывать твердые бытовые отходы с предварительной сортировкой и разделением материалов, пригодных для вторичной переработки. Бібл. 9, рис. 1.

Ключевые слова: биогаз, твердые бытовые отходы, очистка сточных вод, переработка отходов, компост.

Серъогін О.О. ${ }^{1}$, докт. техн. наук, Василенко О.В. ${ }^{1}$, канд. техн. наук, Frank J. Riedel ${ }^{2}$, Helmut Aigner ${ }^{2}$

1 Національний університет харчових технологій, Київ вул. Володимирсъка, 68, 01033 Київ, Україна, e-mail: seryoginoo@ukr.net

${ }^{2}$ Ingenieurplanungsgruppe $\mathbf{G m b H}$, München

27, Christoph-Rapparini-Bogen, 80639 München, Germany, e-mail: Intereng.riedel@t-online.de

\section{Технологічний комплекс з переробки твердих побутових відходів та відходів очисних споруд з отриманням біогазу}

Розроблено концепцію переробки біологічно активного мулу комунальних очисних споруд у комплексі з органічною фракцією твердих побутових відходів способом BioTech. Комплекс, що дає можливість реалізувати запропоновану концепцію, не потребує додаткових земельних ділянок, а класифікована вторинна сировина, біогаз та високоякісне біодобриво, придатне для використання у сільськогосподарській промисловості, є продуктами його діяльності. Запропонована концепція дасть можливість вирішити відразу кілька завдань за рахунок будівництва сміттєпереробного заводу на території фільтрувальної зони існуючих водоочисних споруд. Новий переробний завод буде використовуватися не тільки для обробки й сортування муніципальних твердих побутових відходів, але й для обробки мулу від водоочисних споруд разом з органічними відходами у процесі BioTech, для отримання біогазу й біодобрив - так званого компосту. Новий переробний завод буде екологічно чистим підприємством та, крім інших переваг, зможе переробляти тверді побутові відходи з попереднім сортуванням та розділенням матеріалів, придатних для вторинної переробки. Библ. 9, рис. 1.

Ключові слова: біогаз, тверді побутові відходи, очищення стічних вод, переробка відходів, компост. 